\title{
Some problems in determining the free risk rate of return
}

\author{
Diana Boskovska ${ }^{1}$ \\ ${ }^{\text {I}}$ (Institute of economics_Skopje, Republic of Macedonia)
}

\begin{abstract}
One of the key factors in investment analysis is the risk free rate of return. The interest rate on a government bond is considered a risk free rate of return, but the bond should be free from the risk of nonpayment and reinvestment risk. However, the practical determination of the risk free rate can often be followed by a number of difficulties. Therefore, in this paper we discuss the difficulties faced by an analyst in determining the risk free rate of return on investment and portfolio analysis such as:

- Lack of long-term government bonds on the capital market

- Exposure to the risk of government default

- Change the risk free rate of return over time.

Keywords: capital market, securities, cost of capital, risk, free risk rate of return.
\end{abstract}

\section{INTRODUCTION}

The numerous model od assessment of risk and rate of return start with a financial asset that is defined as the risk-free asset and therefore the expected return of that asset is used as a risk-free rate of return. Then, the expected returns of risky investments are determined in relation to the risk free rate, by adding expected risk premium.

To understand what makes an asset as a risk free asset, it is necessary to consider the way of the risk is measured in investment decisions. Investors who buy assets (financial or real) expect to achieve a yield in the period in which they plan to hold the asset. Realized yields that investors will achieve in a given period may vary and differ from expected returns as a result of the risk that carries the appropriate investment. To some an investment to be characterized as risk-free it needs the realized yields always to be equal to the expected yield.

Such investment is risk free because the realized returns do not vary around the expected yield, i.e. the standard deviation of realized yields in terms of the expected return is equal to zero. [1]

\section{Absence Of Long-Term Government Bonds On The Capital Market}

In many states (and for their currencies), the biggest obstacle in determining the risk free rate of return is that governments issue bonds in local currency. So these states borrow in local currency and are opting for the use of bank loans from international financial institutions like the World Bank or International Monetary Fund (IMF), avoiding thus the financial markets. There are governments that issue bonds, but not in their own local currency, but in any of the currencies of the more developed financial markets. For example, between 1992 and 2006, the Brazilian government issued long-term bonds in U.S. dollars only. In 2008 only three of the 12 South American countries have issued long-term bonds denominated in local currency [2]. There are instances when governments issue long-term bonds, but later offer special discounts to domestic investors or use " forced" to buy these bonds, causing getting unrealistic interest rates for these bonds.

Where there are no long-term government bonds traded, analysts in the valuation of companies often set off by a line of least resistance in assessing the cash flows and discount rates, resulting to the currency mismatch in the valuation process. In this approach, for the risk free rate of return and risk premia is used estimation characteristic for the currencies of developed markets, while for the estimated cash flows is used local currency or they are translated at the current exchange rate in some currency of developed capital markets. For example, the cash flows of local currency are converted into U.S. dollars at current rates, and discount rates are estimated in U.S. dollars. If the valuation is carried out with such cash flows received and discount rate, the result would be with significant error, because expected inflation contained in the cash flows differ from expected inflation contained in the discount rate.

If the government does not issue long-term bonds in local currency (or at least those that can be considered to provide market interest rate), there are two consistent solutions. One is, discount rates to be assessed such as for a developed money markets (instead of local currency) and then turn the cash flows in the currency in which is estimated discount rate, but to the expected, not at the current exchange rate. The second is to try to estimate the discount rate in local currency, but in this situation again appears the problem of assessing the risk free rate. 


\section{Exposure Of The Government To The Default Risk}

The previous analysis was assumed that governments are free from the risk of default, at least in the case when borrowing is done in local currency. This assumption seems reasonable, although can still be controversial for some countries that investors have the perception that their governments are at risk of default even when the loan is made in local currency.

For some countries this assumption still seems unreasonable. The governments in these countries there is a perception that can bankruptcy, even when the borrowing is made in local currency. The possibility of potential bankruptcy of a country can be seen through two types of ratings that make credit rating agencies for most states in case if the loan is made in foreign currency and also in case when the borrowing is made in local currency (the latter is usually larger than the first). Credit rating, when borrowing is done in local currency, in more states under Aaa (Moody's rating for a country that is free from the risk of default).

Table 1 Margin of default risk of certain countries according to Moody's rating [3]

\begin{tabular}{|l|l|l|}
\hline \multicolumn{1}{|c|}{ State } & \multicolumn{1}{|c|}{$\begin{array}{c}\text { Country's rating } \\
\text { (according to Moody's) }\end{array}$} & \multicolumn{1}{c|}{ Margin of default risk } \\
\hline Argentina & $\mathrm{B} 3$ & $6.00 \%$ \\
\hline Brazil & $\mathrm{Baa} 2$ & $1.75 \%$ \\
\hline Chile & $\mathrm{Aa} 3$ & $0.70 \%$ \\
\hline China & $\mathrm{Aa} 3$ & $0.70 \%$ \\
\hline India & $\mathrm{Baa} 3$ & $2.00 \%$ \\
\hline Indonesia & $\mathrm{Baa} 3$ & $2.00 \%$ \\
\hline Malaysia & $\mathrm{A} 3$ & $1.15 \%$ \\
\hline Peru & $\mathrm{Baa} 3$ & $2.00 \%$ \\
\hline Poland & $\mathrm{A} 2$ & $1.00 \%$ \\
\hline Russia & $\mathrm{Baa} 1$ & $1.50 \%$ \\
\hline South African Republic & $\mathrm{A} 3$ & $1.15 \%$ \\
\hline Turkey & $\mathrm{Ba} 1$ & $2.40 \%$ \\
\hline
\end{tabular}

In the event that a state issued long-term bonds in local currency, analysts often determine their interest rates as risk free rates of return, while ignoring the potential risk of default that carry with them. For example, following the practice of long-term interest rate of bonds issued by the Brazilian government and denominated in Brazilian real in September 2012 that totaled 9,45 \% [4] will be used as risk free rate when calculating the cost of equity for the shares and for the total capital of a some Indian company. According to the ratings shown in Table 1, rating concerning to the domestic currency is $1.75 \%$ and clearly indicates that the Brazilian bond denominated in real is exposed to the risk of non-payment and that part of its interest rate is the result of this risk. Although it seems reasonable, that discount rate refers to the Brazilian real to be higher to reflect the risk of the Brazilian government, however embodying this risk in the risk free rate, bearing risk from its double counting. This, as one approach for adjusting the risk premium on equity of shares in emerging markets is added margin for default risk for the appropriate state in which the company operates, to the the market risk premium of equity (shares) estimated for developed markets.

Given that the problem in this case is that the interest rate on bonds denominated in local currency contains margin for risk of default, the solution is pretty simple. If you can estimate how much of the current market interest rate refers to the risk of non-payment, you can subtract the margin for default risk from the interest rate and thus to come to the risk free rate of return.

Again, if used Brazilian denominated bond in real, the margin for default risk will get through ratings of the Brazil for the borrowing in local currency, which is $1.75 \%$. Subtracting this value from the market interest rate, the risk free rate of return will be $7.7 \%$.

\section{Changing The Risk Free Rate Of Return Over Time}

Risk free rate of return used to calculate the price of the equity and of the total capital is equal to the interest rate on long-term bonds free by risk default. However, because the interest rate will change over time, that will have a direct impact on the cost of capital. At certain times the current risk free rate may seem too high or too low, compared to previous values or in terms of economic fundamental factors, so its change in one direction is more likely than in the other direction.

If you observe historical values of interest rates in the U.S., can be derived two conclusions. The first is that they are inconsistent and change over time with greater intensity in certain time periods. The second conclusion is that interest rates in most of the time are in the "normal" range, and deviations from this range are balanced (correct) after a certain period. Fig. 1 illustrates two findings. 


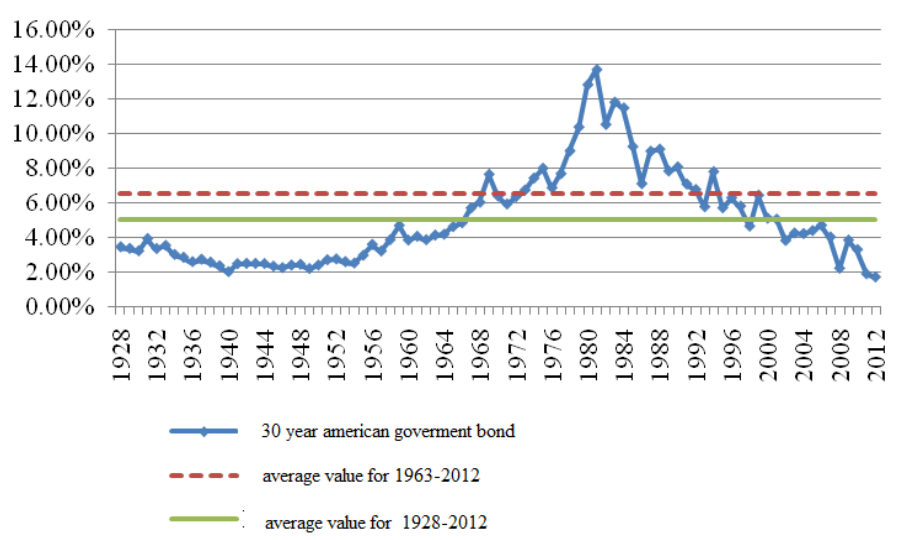

Figure 1 Interest rates on 30 year U.S. bonds (T-Bond) [5]

Although, you can see that there are long periods of stability in interest rates, this stability was impaired by periods of volatile interest rates. So, long period of stability in interest rates in the sixties was followed by a decade of fluctuating interest rates in the seventies. It should be noted that in periods of volatility, interest rates tend to return to the range of 5\% to 7\%, which can be considered "normal range" in the United States. However, this assessment can be considered subjective partly, because it will depend on the period to which it relates. For example, the normal rate is different if we take into account the past 30 years (average interest rate of $6.25 \%$ ) in relation to the past 50 years (average interest rate of $6.6 \%$ ) or to the past 80 years (average interest rate of $5.19 \%)[6]$.

For the interest rates outside the United States, there are fewer historical data, but can say that the volatility of interest rates is much higher in emerging markets, especially in Latin America. This volatility is mainly caused by changes in expected inflation over time. Additionally, determining the normal range of interest rates in these markets is far more difficult, because in these markets in certain periods observed three digit and in other single digit interest rates.

In a situation where analysts are faced with rates that deviate from that they consider as a "normal" range, they make replacement the rate that seems more realistic in the process of evaluation. For example, if the interest rate on government bonds is $3.5 \%$, the analyst may decide to use a rate of $5 \%$ as "perceived" risk-free rate.

Although this approach seems logical, it carries three potential problems. The first problem is that such a "realistic" rate is according to a subjective assessment of the analyst, that different analysts can make a different assessment for such specified rate. The second potential problem is that instead of the current, using the risk-free rate of return which is located in the "normal" range may cause certain effects in the valuation process. For example, using a risk free rate of 5\% when the risk free interest rate of government bonds in the process of evaluating one company will reduce the value of the company and will probably make overestimated. However, it is not clear whether this conclusion is the result of the attitude of the analyst on interest rates (they are too low) or the attitude that has the analyst about the company.

Finally, interest rates generally change over time due to changes in economic fundamental factors. Using "normal" risk free rate which is different from the present one, without having to make adjustments to fundamental economic factors affecting the current interest rate, will result in inconsistent valuation. For example, suppose that the risk free rate is currently low because inflation is unusually low and the economy is stagnant. If risk free rate of return back again in the normal range, it will be the result of the return of the inflation rate back to normal historical levels or for strengthening the economy. Analysts who use "normal" interest rates, in the valuation will have to use a higher rate of inflation and / or real growth rates.

Valuation of individual companies, as a general rule, it is a good idea to apply subjective estimates of interest rates, no matter how well designed and look reasonable. It certainly does not mean that you have to use the current risk free rate of return. It is still possible to use market expectations for interest rates. For example, suppose that the current interest rate on ten-year government bond was $3.5 \%$, which would be risk free rate for the next 10 years. However, you can use information from markets for forward contracts and futures on government bonds to get a feel how markets perceive the expected interest rate for 10 years. Then, so the resulting expected rate of return can be used as a future risk free rate of return. Such sightings in market interest rates may be offered separately, because they affect the total value of shares and of the decisions to allocate capital. Practically, it leaves users of research to decide which aspect of the research will trust more. If they more trust on the macro rather than micro perceptions, will give more weight to interest rate and decisions for allocation of funds (capital). On the other hand, if you have more confidence in the company's analysis than in the views on interest rates, will focus on the company evaluation and recommendations. 
V.

CONCLUSION

Summing up the main points of the article, can list the main rules related to the risk free rate of return:

- Risk free rate should really be free of risk. Rate which in itself has built margin for risk of default or other risk factors can be risk-free rate of return. In this sense, is the assertion that interest rates on government bonds denominated in domestic currency in many emerging markets can be used as risk free rate of return.

- Risk free rate of return should be selected so as to be aligned with the way that certain cash flows are determined. So, in the case of cash flows expressed in real terms, then it should be expressed and risk free rate of return. Also, risk free rate of return should be addressed to the currency in which cash flows are denominated. In other words, when you specify the currency of the cash flows, determines the currency for which the risk free rate of return, whereas currency should not depend on the country of origin of the company or investor who is doing the evaluation.

- Subjective views on interest rates need to stay away from the process of valuing of the companies. In other words, even if there is a belief that the risk free rate of return will increase or decrease over time, there is danger to get a distorted picture when they are applied to evaluation. In case of applying the valuation, you get a result that will presents mixture of subjective views on interest rates and the company being valued, there is no simple way to separate the results of each effect.

Main prerequisites an asset to be treated as a means to free risk are: the yield of such asset to be reliable, that the realized yield is equal to the expected, to be free from the default risk and reinvestment risk. The only securities that can meet the first two conditions, i.e. to provide reliable income and not be at default risk are the long-term government free coupon bond. In determining the risk free rate must considered permanently its dependence on the currency and inflation. The impact of currency resulting from volatility of the interest rates, that is a result from different level of expected inflation for different currencies. In terms of currency, should always be an agreement between the currency in which calculated risk free rate and to use in determining of the cost of capital, with the currency of the cash flows whose present value is calculated. Consequently, the choice of the risk free rate should not depend on the currency of the country of origin or the company which carried out the project, but only from the currency in which the expected cash flows are estimated. In conditions of high and unstable inflation, requires using the risk-free rate in real value. Although government bonds can provide risk-free yield in nominal value, their yield is not risk-free in real terms because inflation can be variable. In such conditions, to determine the risk free rate of return in real terms, the most significant securities that can be used for its determination are the government securities indexed with inflation (Treasury Inflation Protected Securities - TIPS).

\section{REFERENCES}

[1] Boskovska D., The free risk rate of return and factors that affects its assessment, IOSR-JBM, Volume 9, Issue 4, 2013, 88-92.

[2] Damodaran A., What is the riskfree rate? A Search for the Basic Building Block, New York University -Stern School of Business, December, 2006.

[3] Damodaran A., Investment valuation: tools and techniques for determining the value of any asset,(Thrid Edition, Wiley, Hoboken N. J., 2012)

[4] http://www.tradingeconomics.com/bonds-list-by-country.

[5] Damodaran A., What is the riskfree rate? A Search for the Basic Building Block, Stern School of Business, 2008

[6] http://www.stern.nyu.edu/ adamodar/pc/datasets/histretSP.xls 